\title{
RECOBRAR LA MIRADA EN TIEMPOS DE POSVERDAD: EL ESTILO DE PAOLO SORRENTINO ANTE LA OBSCENIDAD EN SILVIO (Y LOS OTROS) (LORO, 2018) ${ }^{1}$
}

\section{RECOVERING THE GAZE IN TIMES OF POST-TRUTH: PAOLO SORRENTINO'S STYLE IN THE FACE OF POLITICAL OBSCENITY IN LORO (2018)}

\author{
Shaila GARCÍA CATALÁN \\ Universitat Jaume I \\ scatalan@uji.es \\ Javier MARZAL FELICI \\ Universitat Jaume I \\ marzal@uji.es
Aarón RODRÍGUEZ SERRANO
Universitat Jaume I
serranoa@uji.es

\begin{abstract}
Resumen: El presente trabajo propone un análisis textual de Silvio ( $Y$ los otros) (Paolo Sorrentino, 2018). Para ello, utilizaremos una metodología basada en las aportaciones de la semiología del cine, especialmente en lo que toca tanto a los procesos significantes de la forma como al despliegue de intertextos que dotan de espesor a la escritura de Sorrentino. Nuestro objetivo es demostrar que tras la aparente relación con los estilemas de la "imagen postmoderna" — la desmesura, la serialidad, la citación...-, se puede poner de relieve un programa ético que responda a los retos contemporáneos de las relaciones entre verdad, representación y política.
\end{abstract}

Palabras clave: Paolo Sorrentino. Análisis textual. Semiología fílmica. Silvio (y los otros).

\begin{abstract}
This paper proposes a textual analysis of Loro (Paolo Sorrentino, 2018). To do so, we will use a methodology based on the contributions of the semiology of cinema, especially with regard to both the significant processes of form and the deployment of intertexts that give thickness to Sorrentino's writing. Our aim is to show that behind the apparent relationship with the stilems of the "postmodern image" - the disproportion, the seriality, the citation...-, it is possible to highlight an ethical programme that responds to the contemporary challenges of the relations between truth, representation and politics.
\end{abstract}

Keywords: Paolo Sorrentino. Textual Analysis. Film Semiology. Loro.

\footnotetext{
${ }^{1}$ El presente texto ha sido realizado en el marco del proyecto de investigación Análisis de identidades discursivas en la era de la posverdad. Generación de contenidos audiovisuales para una Educomunicación crítica (AIDEP), código 18I390.01/1, bajo la dirección de Javier Marzal Felici, financiado por la Universitat Jaume I a través de la convocatoria competitiva de proyectos de investigación, para el periodo 2019-2021.
} 


\section{INTRODUCCIÓN, HIPÓTESIS, OBJETIVOS Y METODOLOGÍA DE INVESTIGACIÓN}

En 2008, año en el que Paolo Sorrentino estrenaba Il Divo para recrear la caída de Giulio Andreotti, siete veces primer ministro, el fotoperiodista Antonello Zappadu retrataba a hurtadillas las orgías de Berlusconi en su residencia en Cerdeña. Estas fotografías fueron decisivas para destapar los escándalos y corrupciones de il Cavaliere. Diez años más tarde, apenas unos días antes de que la Justicia italiana le retirara su inhabilitación que desde 2013 le impedía presentarse a un cargo público, Sorrentino emite en la televisión italiana la miniserie Silvio (y los otros) (Loro), compuesta por dos episodios. Al tiempo que Berlusconi regresa a primera línea de política -en 2019 vuelve a ser líder de la renacida Forza Italia y es elegido eurodiputado en las elecciones al Parlamento Europeo- vuelve a los hogares a través de la televisión. En España, por ejemplo, Silvio (y los otros) llega como serie con Movistar+ pero antes se distribuye un filme en el que se han recortado más de 50 minutos de metraje — los más sórdidos y menos exportables internacionalmente-.

Silvio (y los otros) cuenta un pasaje importante para la política italiana: arranca en 2006, momento en el que Berlusconi pasó a estar en la oposición después de dos legislaturas, hasta volver a ser Primer Ministro de Italia y tener que afrontar sus promesas ante los desastres del terremoto en L'Aquila en 2009. El lenguaje cinematográfico escribe la historia una década después que lo hagan las fotografias: la urgencia de la imagen fotoperiodística no es la misma que la del tiempo de ficción.

Durante estos años de retirada obligada de la vida política — no económica, pues el imperio Berlusconi ha ido extendiéndose en el espectáculo, desde la televisión hasta el fútbol - ha aumentado el escepticismo alrededor de las figuras que detentan el poder. El ascenso de Donald Trump a la presidencia de Estados Unidos en 2016 marca el triunfo de un modelo de política abiertamente vulgar que había impuesto la fanfarronería de Berlusconi en Europa. Así, con la perspectiva del tiempo, Silvio (y los otros) retrata a Berlusconi como síntoma de su tiempo, un momento histórico de debilitamiento de las instituciones y del poder de las leyes y de la corrupción cuando se pergeñó la crisis económica mundial e hizo eclosionar los tiempos de la posverdad, propiciados por tantas mentiras institucionales puestas en órbita por las redes sociales y sus ritmos informativos.

La posverdad ha cambiado no solo el estatuto de la verdad sino el estatuto de la mentira y del pudor (Rodríguez Ferrándiz, 2018). Puede entenderse como la realidad devenida en farsa, como la libertad de expresión malentendida o pervertida, como el intento mismo de la exhibición de lo inefable bajo los filtros de la espectacularización.

Precisamente en tiempos donde el sentido mismo entra en crisis, la ficción es un modo posible de soportar y pensar lo político. Consideramos que la oportunidad de Silvio (y los otros) reside en que al tiempo que lanza una sátira, hace una propuesta ética: la de recuperar la creencia en el tramado simbólico, en el Otro de la palabra. Como ha quedado 
consignado en otro lugar (Rodríguez Serrano, 2017: 91), Sorrentino es un director que, a fuerza de ser considerado únicamente a partir de lo desmesurado de su puesta en escena y de su innegable barroquismo, ha sido extraordinariamente poco pensado en términos estrictamente éticos. Sin embargo, es innegable que en su cine, con el paso de los títulos, se ha ido abriendo cada vez con más urgencia una pregunta por la alteridad que atraviesa las esferas políticas - Il Divo-, la memoria histórica - Un lugar donde quedarse (This Must Be The Place (2011)_, llegando incluso a la pregunta por lo sagrado mismo en los últimos momentos de La gran belleza (La grande bellezza, 2013), e incluso de Silvio (y los otros). La pregunta teológica no es, a nuestro juicio, sino otro ángulo para encarar el problema de la fundamentación del acto ético, escollo mayúsculo de cualquier sistema de creencias posterior a la caída de los grandes relatos y humus del que extrae su venenosa savia el relativismo propio de la posverdad.

Así, si entendemos lo sagrado como la tentativa del hombre para pensar y conjugar lo próximo y lo lejano, incluso "su poder de manejar el significante y ser manejado por él" (Lacan, 2005: 254) entenderemos la urgencia de pensar a Sorrentino en tiempos de posverdad.

Sin embargo, gran parte de la crítica de su última obra ha considerado que Sorrentino aquí ha quedado "absorbido y embriagado de la cultura del exceso que aparentemente pretende criticar" (Rodríguez Torres, 2018: 62) y que "grita bien alto su intención de burlarse de Berlusconi al tiempo que se rinde una y otra vez a la seducción de su obsceno imaginario" (Costa, 2019). Estas posiciones abren un debate sobre las posibilidades estéticas de la sátira en la posmodernidad y, al tiempo, calibran la posición naturalista tanto de teóricos como críticos cinematográficos, frente a un lenguaje audiovisual que reivindica la expresión y que defiende Sorrentino desde primera línea de batalla. Él es, quizás, el autor que más sofistique un trabajo de la puesta en escena —que, en el cine, especialmente en el de terror, se ha visto afectado por la crisis económica - y la caligrafía cinematográfica - "la asignatura por la que oposita Sorrentino lleva el marbete de calicinematografia" (Rubio Alcover, 2012: 234) — . En una línea de guion, la mujer de Berlusconi en Silvio (y los otros) le reprocha: "No te revelas nunca, ni siquiera a mí. Eres una larguísima e ininterrumpida puesta en escena, Silvio". Ante la incapacidad para revelarse que rodea al político — que, a pesar de los juicios, de las condenas, siempre vuelve a la política con más ímpetu impostor que nunca- creemos que es fundamental lo que puede mostrarnos la dispositio hermenéutica de Sorrentino, importante intérprete de nuestro tiempo.

Por todo ello, esta investigación tratará de demostrar a modo de hipótesis que Silvio (y los otros) no cae en la obscenidad y en el exceso de lo que representa porque no se adscribe a la tradición naturalista a favor de un cine transparente, sino que reivindica un cine de la expresión. Precisamente su posición ética emerge de las decisiones enunciativas - especialmente sobre la puesta en escena- que le permiten trascender la sátira para construir un retrato de Berlusconi y hacer una propuesta ética: en tiempos de la posverdad, recuperemos el misterio. 
Nos proponemos los siguientes objetivos:

1. Señalar cómo las decisiones formales de la enunciación sobre puesta en imágenes toman una posición ética ante la obscenidad que se representa.

2. Analizar cómo la sátira sorrentiniana señala sobre qué fantasías y mitos fundamentales se construye el poder contemporáneo y la figura de Sorrentino en concreto. De este modo, advertiremos cómo la obra reclama una responsabilidad al espectador.

3. Analizar cómo el estilo de Sorretino trasciende la sátira y el riesgo de la caricatura a través de un esfuerzo de poesía visual que busca la complejidad del personaje desde el universo sorrentiniano, siempre a la espera de la recuperación de la sorpresa, de lo insólito. Propone, por lo tanto, recuperar el misterio.

Para ello, y partiendo de la idea de que, como apunta Žižek, "el inconsciente está expuesto, no oculto por una profundidad insondable [...] [y por tanto] la exterioridad material resulta muy útil en el análisis de cómo se relaciona la fantasía con los antagonismos inherentes a la edificación ideológica" (2011: 11), analizaremos la superficie textual de Silvio (y los otros) siguiendo la metodología del análisis textual que proponen estudiosos como Aumont y Marie (1990), Carmona (2006) o Marzal y GómezTarín (2007) para determinar las claves enunciativas de "la puesta en imágenes" (Català, 2001) y, extraer, desde ella, la propuesta ética de Paolo Sorrentino. Es necesario reivindicar, por lo tanto, una aproximación semiótica en el tratamiento de los procesos de significación (Zunzunegui, 2005), que permita la exploración tanto de huellas narrativas como formales. La estructura de nuestra propuesta tendrá que encarar, por lo tanto, un doble movimiento: en primer lugar, la revisión de los rasgos propios del cine de Sorrentino en su relación con la sátira y la parodia y, posteriormente, el estudio detenido de la manera en que cuerpo y poder quedan enhebrados en una posición casi biopolítica.

\section{MARCO TEÓRICO}

\subsection{Sorrentino: un estilo contra la transparencia}

A pesar de su posición sobre el realismo, Bazin decía que "la imagen cinematográfica puede vaciarse de todas las realidades excepto una: la del espacio" (2004: 186) porque éste era el signo de su especificidad del cine. La escritura de Sorrentino emerge, en primer lugar, definida por un replanteamiento completo de las relaciones entre cámara, movimiento y espacialidad. Las violentas líneas compositivas que dividían los interiores de Las consecuencias del amor (Le conseguenze dell'amore, 2004), los arabescos circulares rodados en gran angular que deformaban los puntos de fuga en This must be the place, o incluso las espirales que la mirada trenza entre los personajes de The New 
Pope consigue que la dimensión espacial de cada encuadre se experimente al mismo tiempo contundente y artificial.

Sorrentino canibaliza el espacio: las postales turísticas en la Roma de La Gran Belleza, los espacios cálidos y confortables del reposo neoliberal en La juventud (Youth, 2015), los espacios propios de la política italiana en Il Divo. Su caligrafía se vale de los referentes para torcer los procesos de significación: montaje alternado que genera extraños e imposibles raccords —el cadáver y el grito que arrancan el prólogo de La Gran Belleza-, secuencias de escenas que remiten al videoclip o al discurso publicitario, personajes apenas esbozados que hacen mutis proponiendo el enigma de su propia existencia.

Ciertamente, a Sorrentino se le ha calificado, quizá con demasiada rapidez, de "cineasta postmoderno". Esto únicamente tendría sentido si, siguiendo a Daney (2004), aceptásemos que tras su escritura siempre se remite a una imagen previa, a un icono anterior - el cantante de The Cure, una cinta de Fellini, un retablo vaticano-. La diferencia es que el proceso de citación en Sorrentino no es simplemente un juego que busca la extracción del placer por el reconocimiento, sino una búsqueda calibrada de aprovechar al máximo la fricción entre significantes. El caso de Silvio es preclaro para entender esta problemática. Tras sus imágenes se encuentra por un lado el propio delirio de cuerpos sexuados, jóvenes y en perpetuo ofrecimiento que caracterizó la marca de estilo básica de la televisión de Berlusconi. Las Mamachicho hispánicas no son sino el germen - todavía ingenuo, pero ya destructivo - de las fiestas orgiásticas con las que los ingenuos intentan llamar la atención del político protagonista. En otra dirección, Silvio dialoga explícitamente con Il Caimano (Nanni Moretti, 2006), otra película rodada explícitamente para frenar el ascenso al poder de Berlusconi (Rodríguez Serrano, 2018: 304-307) y que utilizaba, como motor básico, la idea de que el cine podía y debía actuar contra el universo de imágenes televisivas desatadas. Nota bene: Sorrentino mismo realizaba un cameo en los primeros minutos de la cinta de Moretti, escribiendo su rostro y su cuerpo en un programa político que condensó toda la ideología y la tensión acumulada durante décadas por la izquierda extraparlamentaria italiana.

La transparencia, como generalmente ha sido definida (González Requena, 2006), implica una coherencia interna del mundo, la confianza en un cierto modo del relato que garantiza un saber sobre el que se disponen los acontecimientos de la trama y que tiene, en su clausura, la garantía misma de ese orden interno (del mundo, del relato). Cuando Sorrentino la niega, está desligándose de esa posibilidad de una unicidad de la verdad del mundo, sin que por ello implique ni por un instante que sus imágenes no busquen, obra tras obra, la posibilidad de lo que Zumalde y Zunzunegui han denominado, con gran precisión, la verdad cinematográfica (2019). Una verdad que habrá que buscar, por tanto, en otro lado: en su relación con la sátira. 


\subsection{La sátira audiovisual en la crisis}

El cine no deja de alzar sátiras contra las figuras de goce que corroen las estructuras de poder - desde la banca hasta la política - atravesando diferentes géneros. El lobo de Wall Street (Martin Scorsese, 2013) lo hace desde la saturación y la desinhibición del exceso. En la fina línea que recorre las relaciones entre la política y la ironía (Hutcheon, 1994), podemos observar cómo las propuestas fílmicas desplegadas desde la crisis de 2018 siguen validando las teorías de Jessica Milner Davies (2003) sobre la fuerza corrosiva de la farsa misma. Dicha autora, a partir de su exploración historiográfica de los recursos cómicos e irónicos, propone toda una reestructuración del campo dramático del cual Sorrentino es, sin la menor duda, uno de los más avezados herederos. De hecho, siguiendo las contribuciones al campo de Nicholas Holm (2017), el humor ha ido ganando centralidad en el espacio político, desbordando los límites del entretenimiento hasta convertirse en un pivote central sobre el que la propia construcción de la ciudadanía despliega su complejo tapiz de identidades. Desde el género de terror, con Déjame salir (Get Out, 2017) y Nosotros (US, 2019) Jordan Peele denuncia la segregación racial ante la llegada a Donald Trump a la presidencia en EE.UU. El reino (Rodrigo Sorogoyen, 2018) es un incisivo paseo por la corrupción política española. El estreno de la miniserie de Silvio (y los otros) en España coincide con el de La voz más alta (Tom McCarthy, Alex Metcalf, 2019-) sobre Roger Ailes, fundador de Fox News. Estas obras tratan de escribir el desamparo de los ciudadanos ante la opulencia y la obscenidad de un poder que ya no disimula: sabe que vivimos en tiempos de una profunda crisis de creencias. El sujeto contemporáneo se encuentra desheredado del Otro simbólico (García-Catalán, 2018).

En un principio, podríamos pensar Silvio como otro relato sobre la crisis financiera y política de 2008 que, como apuntan Marzal y Soler (2018) se postulan como reconstrucciones ficcionales de hechos reales, dirimiéndose entre el documental y ficción, a través del impacto de la visualidad y el exceso, un montaje sincopado y la construcción de personajes entre la identificación y el distanciamiento. Sin embargo, como analizaremos, Sorrentino toma distancia respecto a las producciones mainstream que exportan el imaginario audiovisual norteamericano en su reivindicación de su estilo y, aunque despliega esa "belleza volátil”" (Marzal y Soler, 2018: 43) que caracteriza a este cine de la crisis, propone cierta recuperación de la mirada y de la creencia a través de la belleza que emerge de los escombros de Italia. En esta dirección, qué duda cabe, Sorrentino dialoga con una tradición específicamente mediterránea que se ha valido de la apropiación de los géneros populares (Castro de Paz y Cerdán, 2011) para resituar la figura del bufón, la picaresca o la denuncia social a partir de códigos específicamente significantes que desvelan o ponen en crisis muchos de los lugares comunes de la acción política.

La sátira, que nace en Grecia pero encuentra su esplendor en la vida pública romana, hoy no se entiende tanto como un género sino como un tono en la obra artística: 
Tiene siempre como propósito representar la realidad cotidiana con el fin de poner de manifiesto, ridiculizar o censurar los defectos y vicios humanos, personales o colectivos, para desarraigarlos (Lázaro, 1996: 228).

Por tanto, toda obra satírica expresa y declara su posición sobre el objeto que representa y parte de una posición moral. Uno de los rasgos de la sátira reside en que, para alcanzar al público, practica la claridad y la sencillez. Por ello, uno de sus mayores peligros es trazar personajes con pocas aristas u hondura psicológica, es decir: cae en una caricatura.

Sin embargo, el estilo de Sorrentino detesta la economía narrativa. No sabe de atajos. $\mathrm{Su}$ discurso despliega disquisiciones, aguijonea en largos diálogos y prefiere las esperas. Asume la languidez propia de cierta modernidad, aunque de pronto la irrumpa con secuencias de escenas aceleradas. La complejidad con la que estudia y retrata a los personajes es uno de los estilemas de Sorrentino más reconocibles: sus películas y series gravitan sobre un personaje-película. La sátira de Sorrentino es especialmente particular porque incluso "ni siquiera cuando hinca el diente en la yugular de sordideces y miserias y chupa la sangre, llega a la infamia de rebajar o de hacer irrisión de sus criaturas, que conservan [...] la grandeza del enigma" (Rubio, 2012: 233). Por ello, a veces Sorrentino defiende que Silvio no es una sátira en tanto trasciende su objetivo: "No era cuestión de ponerse berlusconista o antiberlusconista. No es un ataque y, ni mucho menos, una defensa. [...] El sentido era indagar en la dimensión de los sentimientos detrás de los personajes" (en Verdú, 2018).

La sátira requiere cierta distancia, cierto vuelo sutil en la utilización del decir indirecto u oblicuo de aproximación a su objeto. La retórica formal de Sorrentino provoca el distanciamiento con el espectador. Sin embargo, precisamente porque aloja lo enigmático, acaba implicándolo en la lógica de lo humano y lo trascendental.

En tanto el cometido principal de la sátira supone un ataque crítico a la realidad, no puede prescindir de referencias a ella. En Silvio apenas hay indicadores cronológicos — salvo sutiles elipsis marcadas por la puesta en escena - mientras, como señalábamos antes, la relevancia de la espacialidad es casi total. Tampoco hay indicadores históricos claros: se barajan nombres reales con nombres ficticios. Se nos advierte al inicio de la película que lo que vamos a ver es fruto de la libre e independiente creación de los autores: "la relación con personas reales y hechos acontecidos tiene como finalidad su reelaboración y reinterpretación en clave artística. Por lo que está completamente desprovista de cualquier pretensión periodística". Y, después de la aparición de los logos de las productoras cita a Giorgio Manganelli, uno de los escritores italianos más barrocos. Leemos: "todo documentado, todo arbitrario". En ese "todo documentado" la enunciación reivindica así el rigor del saber que emerge de la creación artística, que no es inferior al de una investigación periodística, sino que encuentra su potencia en el efluvio de la imaginación (véase el ya citado trabajo de Zunzunegui y Zumalde). Aunque el documental nació para tratar de estudiar un núcleo de lo real que se suponía que la ficción no podía alcanzar, muy pronto algunos documentalistas advirtieron que esto no era 
posible sin los recursos de la ficción. Y es que como apunta Català, "solo se puede sobrepasar la fantasía de lo real, apelando a la imaginación" (2012: 262). Ese "todo arbitrario" de Sorrentino nos invita a quedar libres de los juicios, los hechos y las comunicaciones para pausar las fauces de la posverdad. Silvio habla de una verdad dicha a gritos, denunciada y desvelada pero que durante un tiempo no pudo juzgarse en los tribunales porque Belusconi, mentira tras mentira, llegaba al poder y cambiaba la ley para no ser juzgado. De ahí que Moretti terminase su película de 2006 con un tribunal italiano en llamas. De ahí que, como apunta, Espigado, la sátira "más que descubrir verdades, las libera" (2017: 14). Sorrentino, autor de lo insólito, no deja de añadir sorpresa a lo ya dicho.

Ahora bien, para desvelar en qué podría consistir esta verdad del texto es necesario, como señalábamos anteriormente, realizar un ejercicio de análisis textual del discurso. A ello nos dedicaremos en las siguientes páginas.

\section{ANÁLISIS TEXTUAL}

\subsection{Ellos}

Il cavaliere se hace esperar: aparece a la hora en la miniserie y al tercio de metraje en el filme. Las primeras pinceladas de Sorrentino lo construyen no como un sujeto que goza sino como un extraño objeto de deseo. Lo presenta inaccesible, en boca de todos pero fuera de campo, lugar opuesto a la composición fotoperiodística que requiere cazarlo en el interior del encuadre para colocarlo en el dardo de la denuncia —o de la exaltación-. Él es un núcleo — LUI, en grandes mayúsculas - alrededor del cual se sitúan ellos - como sugiere el título italiano: Loro-, los que mandan o ansían poder. O, como sugiere el título en español, Él es Silvio, en mayúsculas, una suerte de Otro alrededor del cual se sitúan los otros, los que quedan entre paréntesis: Silvio (y los otros). Así, Berlusconi no se construye tanto sobre lo que él goza sino por el camino de goce que despliega. Por extensión, la enunciación también pide responsabilidades a todos aquellos que sostienen — sostenemos - la fantasía de poder: entre el 'Él' y el 'ellos' siempre hay un 'nosotros'. Al igual que Pío XIII (Jude Law) sabía que la fuente misma del poder es la invisibilidad, nuestro metraje también sabe que nada hace tan excitante a un personaje como la dilación en su presentación.

\subsubsection{Los amos sin rostro}

Una de las fantasías fundamentales de nuestra sociedad, clave para pensar la política es la teoría de la conspiración que se sostiene sobre la mítica idea que "detrás del Amo público (quien es, desde luego, un impostor) hay un Amo oculto que mantiene efectivamente, todo bajo control" (Žižek, 2011: 102). Esto se agudiza especialmente cuando se destapan escándalos de corrupción: el amo invisible parece aún más 
insondable. Como avanzábamos, a Sorrentino no le interesa tanto el amo visible, el político de portada, como el amo invisible que ostenta el guion de la vida y está alentado por otros amos sin rostro. Esto se aprecia con claridad en la duplicidad entre el banquero Ennio Doris (Fig. 01) y el propio Berlusconi (Fig. 02), interpretados ambos por el propio Toni Servillo.
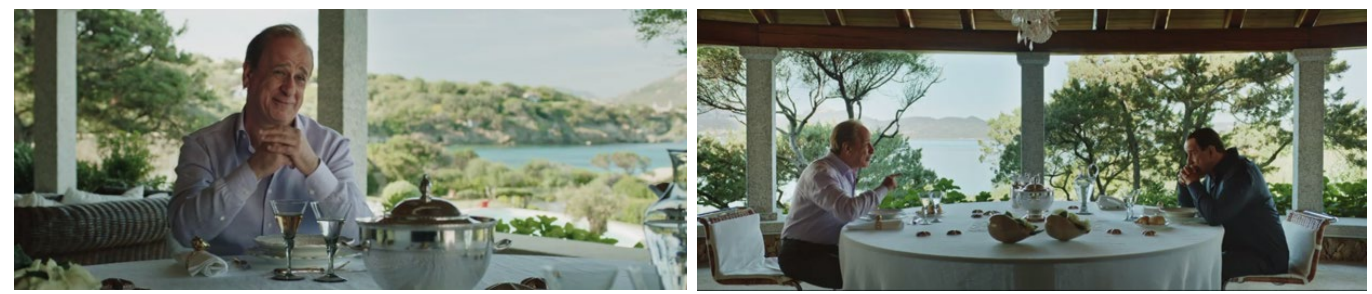

Imagen 01 y 02: Silvio (y los otros) de Paolo Sorrentino.

Ennio Doris, uno de los hombres de banca más ricos de Italia y del mundo, es el que idea el plan y la estrategia para que Berlusconi vuelva a la política convenciendo a seis senadores. Cumple, por tanto, la función proppiana del destinador, al menos en la segunda parte del metraje. Esta decisión de puesta en escena abre distancia en la identificación, agudiza la parodia y tiene un irremediable efecto cómico —Ennio dice que "nadie puede salir de sí mismo", cuando la puesta en escena los desdobla a modo especular-. Pero, ante todo, este recurso muestra que el rostro de la política es el de la banca o que directamente la política es política económica.

El otro "amo invisible" es un hombre al que llaman Dios "porque nadie lo ha visto" - aunque, como desarrollaremos, Dios (al menos el cristiano) es el que precisamente se puede intuir en la mirada - Como una divinidad que reclama sacrificios pide al círculo que rodea a Silvio una mujer. Sergio le consigue a Stella, quien "no es como las otras". La puesta en imágenes del encuentro entre Dios y Stella (Figs. 03 a 08) se planifica con todo patetismo.
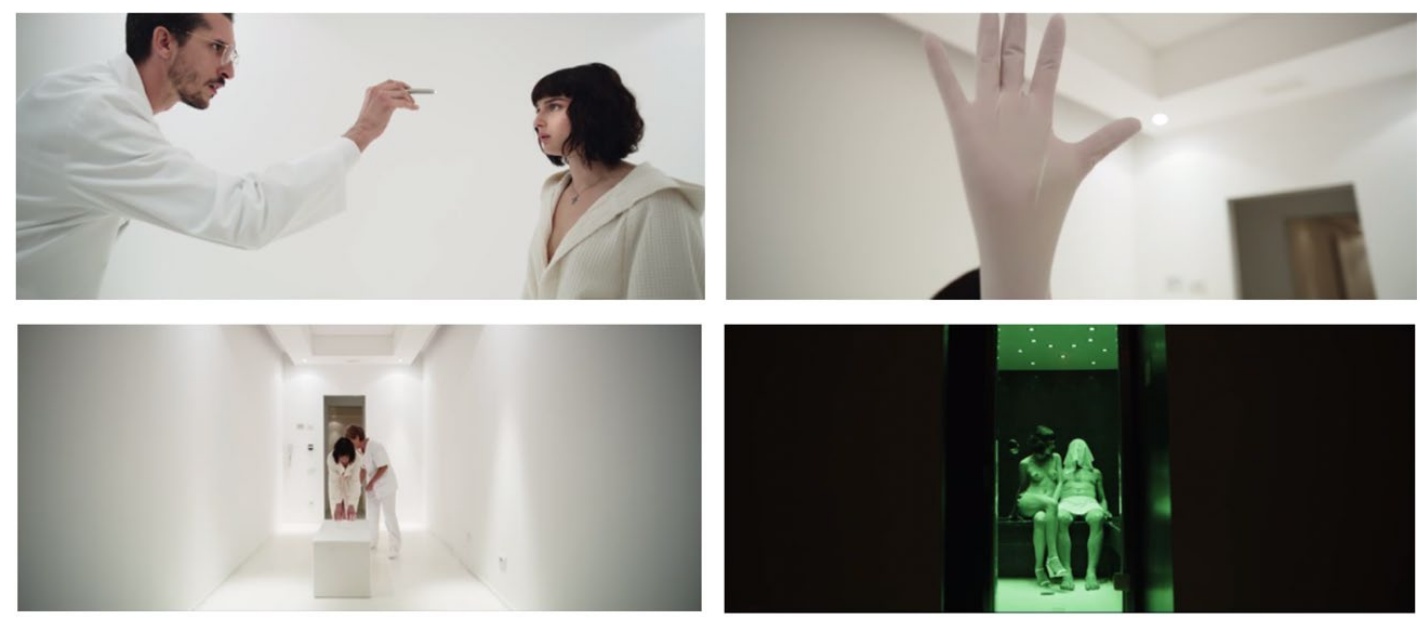

Imágenes 03 a 06: Silvio (y los otros) de Paolo Sorrentino.

(C) UNED. Revista Signa 31 (2022), pp. 373-400

DOI: https://10.5944/signa.vol31.2022.29442

ISSN digital: 2254-9307. ISSN papel: 1133-3634 
Stella entra en una estancia angosta y blanca para ser examinada por tres profesionales que garantizan que está "limpia". La cámara toma distancia para encajonar a la chica en lo que parece la antesala del horror, pero se aproxima para escrutar su rostro de angustia, su cruz sobre el cuello y el guante médico. Cuando Stella entra en la sauna, Dios está desnudo pero oculto por dos toallas: una en el rostro y otra sobre su regazo. Del blanco clínico pasamos a una escena oscura, iluminada por colores que aportan un erotismo fallido. "Escoge bajo qué toalla quieres acariciarme. La toalla podría caerse, en ese caso, asumirás las consecuencias de tu elección" — le dice con un distorsionador de voz-. Tras hacer, un ademán de destapar su rostro, ella opta por la otra toalla, "la más limpia", como reconocerá cuando Berlusconi le pregunte. Él eyacula a los segundos.

Ese ademán fugaz de Stella — con nombre de luz y esperanza — de retirar la toalla del rostro de Dios nos evoca el pasaje bíblico del velo de Verónica, pasaje fundamental para entender cómo la cristología legitima la creencia de nuestra cultura occidental en las imágenes - Verónica resuena a vera icon- En el calvario hacia la crucifixión, la mujer limpió el rostro de Cristo con un blanco paño sobre el que impresionó su imagen. Esta imagen-impronta de Cristo de frente, ocupando la totalidad del lienzo y revelándose es, como apunta Azara (2002: 70-71), la última imagen que Cristo legó a los hombres y que marcó el modelo de retrato occidental. La sugerencia de este pasaje agudiza lo sórdido de la escena de Silvio — a su vez recortada de la serie, velada para el filme internacional—. Frente a un Cristo que se deja representar y se ofrece en una imagen reliquia que contacta con el amor y la verdad, el Dios de Silvio niega su rostro porque clama el triunfo del goce en las aguas de la posverdad.

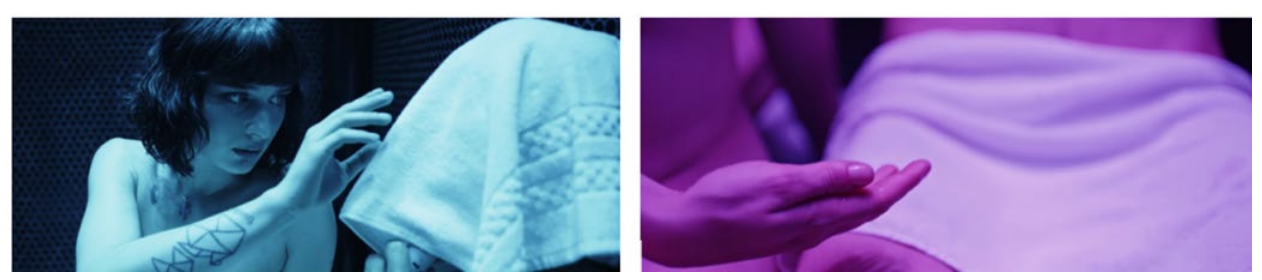

Imágenes 07 y 08: Silvio (y los otros) de Paolo Sorrentino.

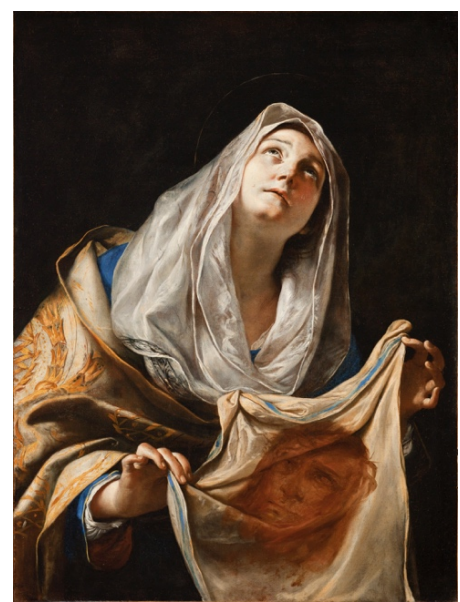

Imagen 09: Santa Verónica con el velo de Mattia Preti. 
Stella, que en tanto figurante aspirante a actriz reclama el reconocimiento de su propio rostro, le pregunta: “¿No quiere saber cómo soy?” La negativa de Dios muestra que el poder niega el rostro porque supone el principio de acceso a la ética, al discurso y al otro. Como apunta Lévinas:

La piel del rostro es la que se mantiene más desnuda, más desprotegida. La más desnuda, aunque con una desnudez decente. La más desprotegida también: hay en el rostro una pobreza esencial. [...] El rostro está expuesto, amenazado, como invitándonos a un acto de violencia. Al mismo tiempo, el rostro es lo que nos prohíbe matar (2000: 71-42).

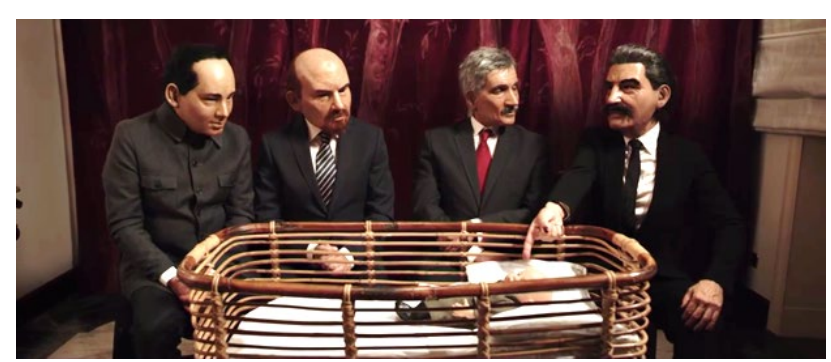

Imagen 10: Silvio (y los otros) de Paolo Sorrentino.

Por ello, los políticos se ponen literalmente máscaras para representar farsas en la intimidad de sus hogares (Fig. 10) y en otro Berlusconi reivindica explícitamente que la gestión política implica precisamente que los rostros no se crucen: "El contable que me administra las cuentas no tiene que cruzarse con mis seres queridos, los hombres de la política con los de la tele". Cuando negocia con la televisión para exigirle que su amante Kira protagonice el biopic de Lady Diana, el montaje apuesta por fragmentar al máximo la pantalla partida. El mosaico visual escinde y separa bustos que escuchan sin ver, bustos que conversar sin mirar, bustos que interpretan sin sentir porque son cuerpos sustituibles al capricho del poder. Desde luego, el filme trata de escribir el miedo a la mismidad de los rostros, a las identidades vacías - como muestran los rostros iguales de los jarrones que decoran las vistas del despacho de Berlusconi (Fig. 11) - o a no poder reconocerse: "La vida es dura sin saber hacer nada. Y al final de los jueguecitos quedará el espejo y al final tú y yo no podremos ni acercarnos", confiesa Kira a Sergio mirando al cielo desde una azotea romana mientras una mirada cenital toma distancia ascendiendo al cielo (Fig. 12). 


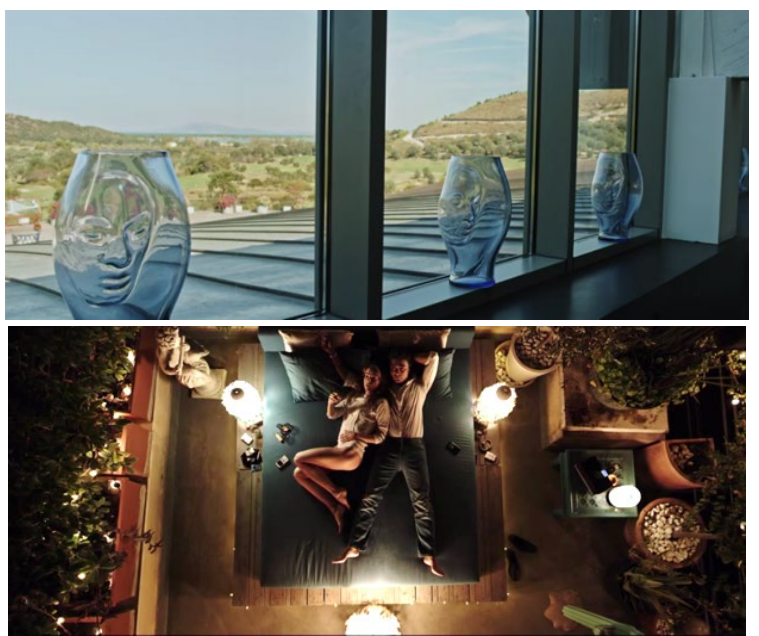

Imágenes 11 y 12: Silvio (y los otros) de Paolo Sorrentino.

\subsubsection{Sergio Morra (Ser Yo Roma)}

La primera parte del relato, hasta que aparece Berlusconi, se construye hilvanando fundamentalmente el punto de vista de Santino, un aspirante a ministro ${ }^{2}$, y de Sergio Morra, inspirado en el empresario Gianpaolo Tarantini, quien alquiló en el verano de 2008 una casa cercana a la de Silvio Berlusconi en Cerdeña y confesó ante el juez haber organizado fiestas con prostitutas de lujo y velinas para él. Su presentación es chabacana. En alta mar, habla sobre hemorroides con un hombre poderoso con el que negocia una ayuda para comedores escolares llevándole a una prostituta. La imagen que lo "inspira" es el rostro de Berlusconi tatuado en el trasero de ella (Fig. 13). Los créditos - tanto en la serie como en el filme- se inscriben desde es contraplano de Sergio al descubrirlo (Fig. 14). Silvio es la cara de un goce obsceno cuya sonrisa siniestra marca para siempre los cuerpos y los deseos de los personajes: en el nombre Sergio Morra resuena la pasión de "Ser Yo Roma".
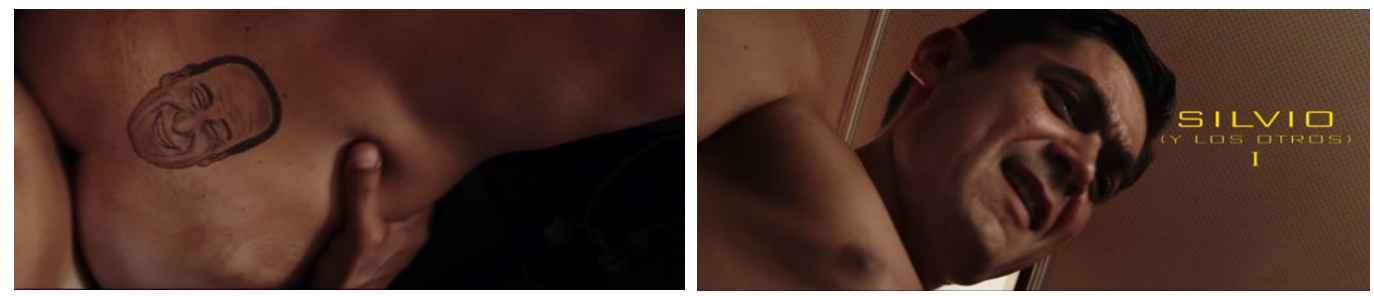

Imágenes 13 y 14: Silvio (y los otros) de Paolo Sorrentino.

La enunciación no da indicadores o coordenadas temporales, pero sí de lugar. El salto de Apulia a Roma se realiza a través de una elipsis temporal desde el salto mortal de esa prostituta, que, para más ironía, se llama Cándida.

\footnotetext{
${ }^{2}$ Inspirado en Sandro Bondi, el ex ministro de cultura y ex portavoz de Silvio Berlusconi y de Roberto Formigoni, ex presidente de Lombardía.
} 
Ya en Roma, el salto a Cerdeña y el encuentro con Berlusconi lo avanza una escena surrealista y ácida. Sergio Morra y las mujeres pasean por Roma dirigiéndose hacia una cena esperando encontrarse con Silvio. Justo después de que advierten su paso en coche, escoltado, una rata de alcantarilla hace descarrilar un camión que viene dejando al fondo el Coliseo: "Las ruinas hablan silenciosamente en contra del avance sin miramiento, son el recordatorio del pasado y, por ello, constituyen un lastre que frena la proyección de la imagen" (Català, 2012: 210). El camión cae a cámara lenta, enmarcado por el Arco de Constatino - arco de triunfo para el festejo del emperador - hasta caer al lado de las columnas y estallar. La basura salta por los aires - en uno de los planos el punto de vista los mancha- mientras los jóvenes contemplan estupefactos la escena mirando hacia un cielo del que solo cae basura. Un fundido nos lleva de la mirada enigmática en la noche de Roma a la mirada alucinada que abraza la droga en Cerdeña.
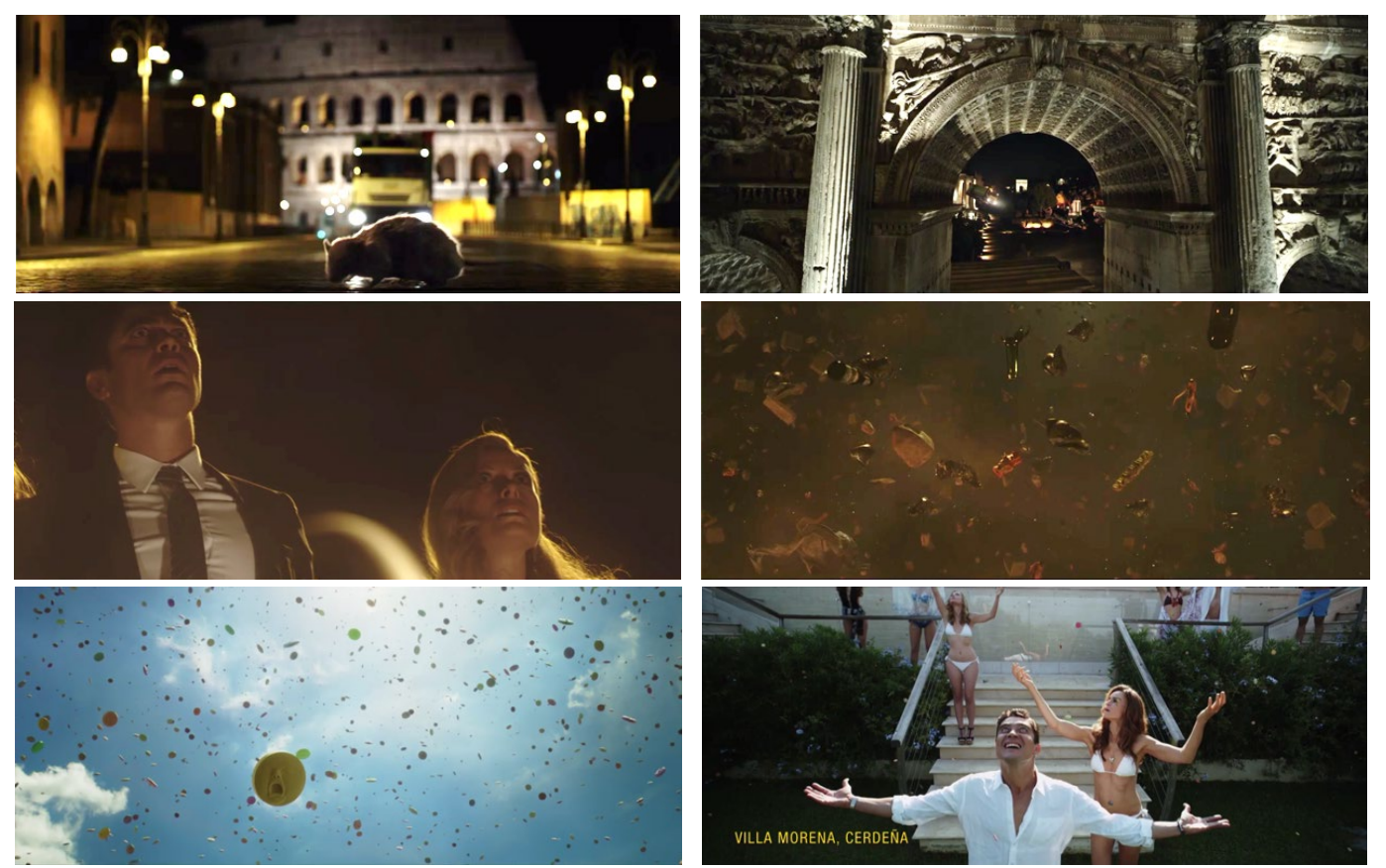

Imágenes 15 a 20: Silvio (y los otros) de Paolo Sorrentino.

Y, aun así, Silvio tarda en aparecer. De ese tiempo cristalizado de las ruinas en la noche, el relato va al tiempo sin tiempo de las drogas. Ya en Cerdeña, Sergio convoca cuerpos alucinados que bailan con todo deleite y gozan hasta el amanecer esperando la llegada del sol y la mirada del rey, hasta parecer estatuas (Fig. 21). "Deberíamos estar siempre así", dice Sergio. "Deberíamos quedarnos siempre así", repite Kira, mientras un gran plano general muestra a todos los jóvenes mirando hacia la villa Silvio, hastiados de componer una continua puesta en escena para la mirada de Berlusconi, ese "insatiable baby" — como canta la canción "Happened" de Perera que bailan-. 


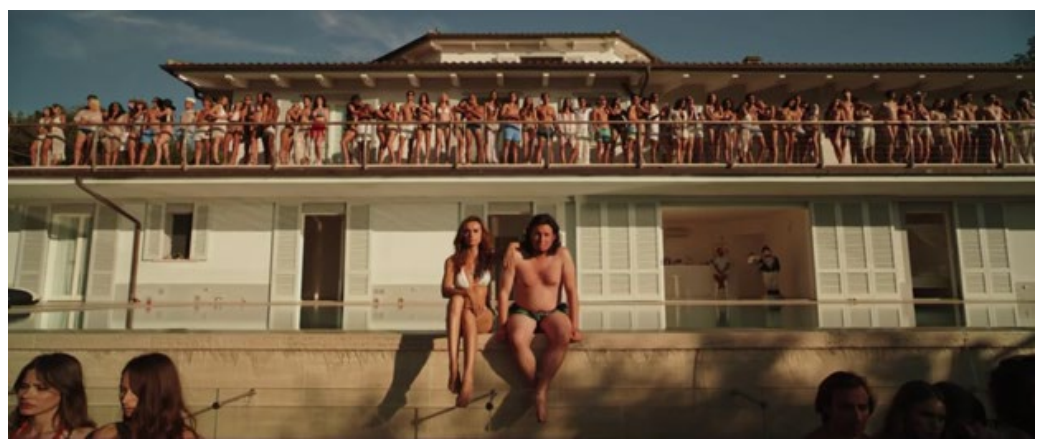

Imagen 21: Silvio (y los otros) de Paolo Sorrentino.

\section{2. Él}

Silvio Berlusconi toma cuerpo en el relato como espectador de esa puesta en escena, orquestada en exclusiva para él. Pero preservando el misterio sobre su identidad se muestra de espaldas y disfrazado de bailarina árabe: también él participa de otra puesta en escena porque está intentando reconquistar a su mujer, Verónica. Volvemos a estar, sin duda, en el territorio del velo: ese cuerpo negado por el metraje, esa mujer cuyo nombre remite precisamente a la fijación del rostro sagrado, esa posibilidad de sugerirse - a través de una toalla, de una llamada telefónica-, y de darle al espectador lo más preciado: el rostro del protagonista (Fig. 22).
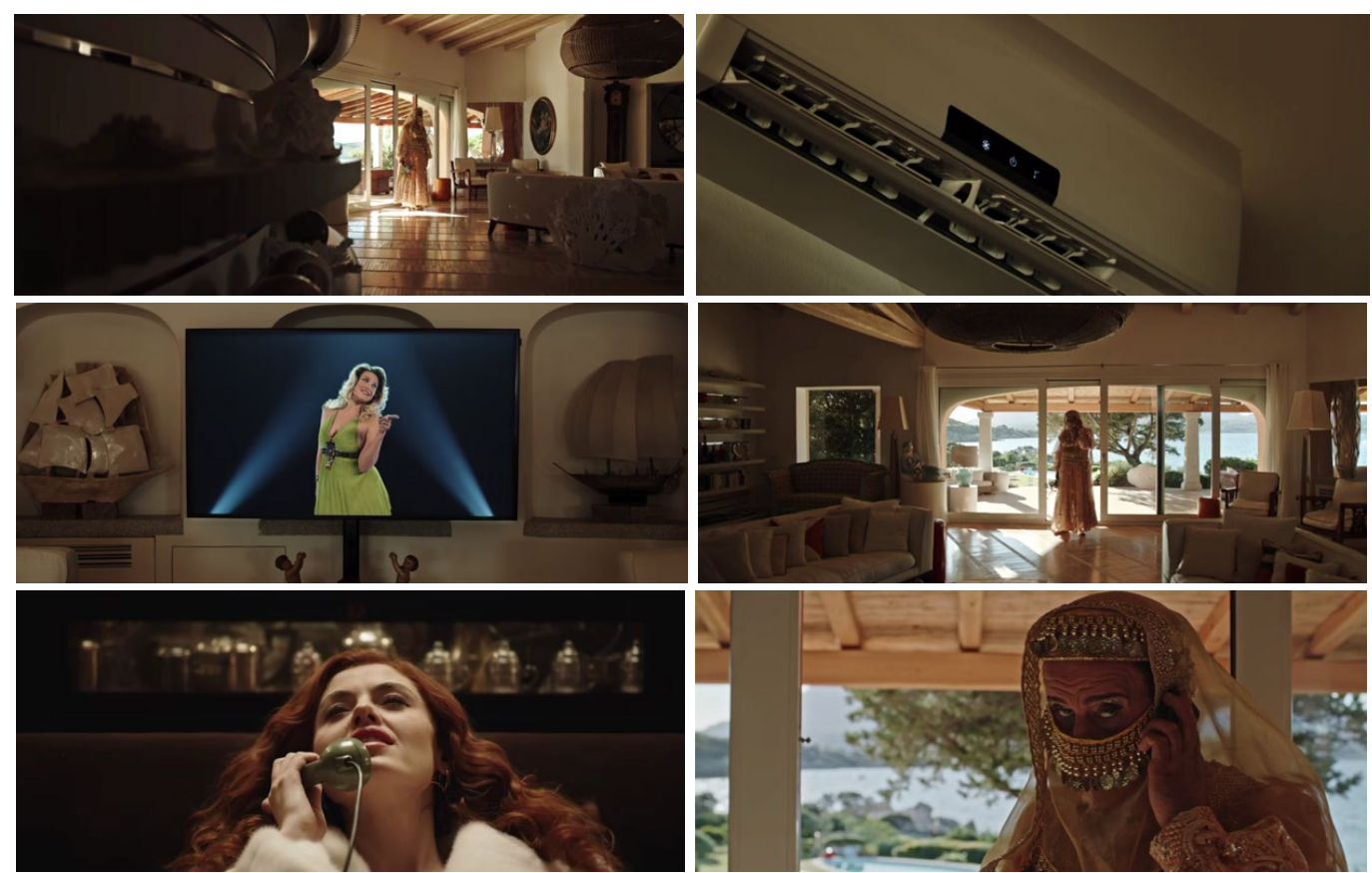

Imágenes 22 a 27: Silvio (y los otros) de Paolo Sorrentino.

La puesta en escena y la planificación de esta secuencia rima y reescribe el prólogo, otro momento surrealista. Allí, una nana de Sergio Bruni nos invita a despertar — “nun cchiù durmi!"' (no duermas más)—, mientras una oveja abre los ojos y mira al espectador, 
espejándolo (Figs. 28 y 29). Con casi exacta planificación y punto de vista de la cámara la oveja entra en casa, ve un concurso televisivo —el mismo que veía Berlusconi (Figs. 24 y 30) - hasta que el aire acondicionado la mata (Figs. 23 y 34). Como apunta López, este arranque supone "una representación del ciudadano medio italiano $-\mathrm{y}$, nos dejamos llevar por el escepticismo político, de la inmensa mayoría de países- que recibe un funesto destino embelesada por dos placeres mundanos para el ciudadano de a pie: la televisión y el aire acondicionado (2019). El desprecio por el ciudadano que la política del espectáculo de Berlusconi practica al tratarlo como un espectador infantil - que esa misma política mediática construye - se confirma en una línea de diálogo de Santino: “el promedio de la audiencia italiana se corresponde con el nivel mental de un alumno de segundo grado".
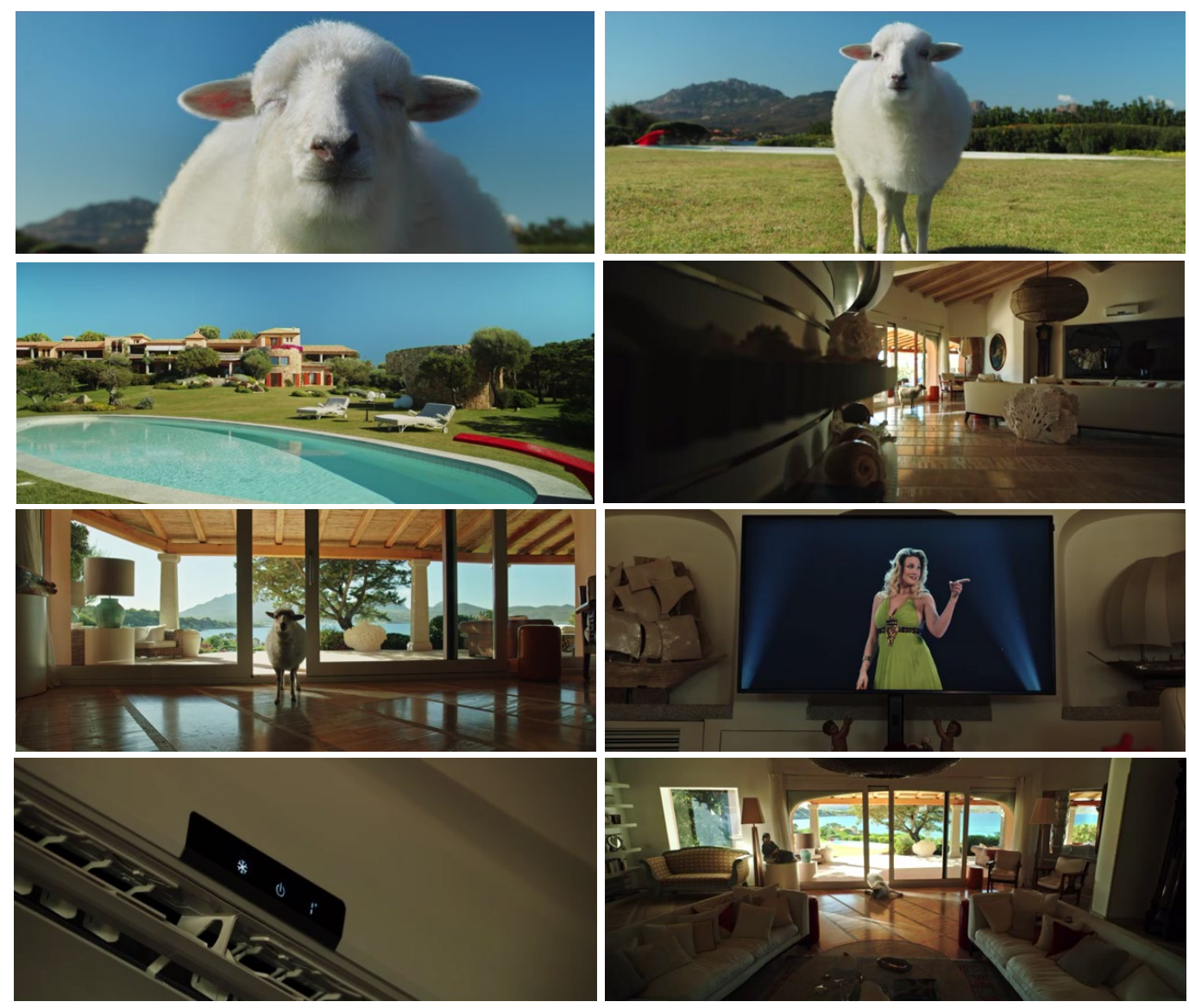

Imágenes 22 a 35: Silvio (y los otros) de Paolo Sorrentino.

Pero la ironía enunciativa se redobla cuando, al reescribir el prólogo en la escena de presentación de Belusconi éste sustituye en el plano a la oveja (Figs. 25 y 35). Aunque esto pudiera parecer un presagio del ocaso de Il Cavaliere más bien retrata su capacidad para vaciar los rostros de vida. Esto lo confirma un efecto de montaje. El plano que sigue inmediatamente al del entierro de la oveja (Fig. 36) nos muestra a Verónica encerrada en el saltador del jardín, con una expresión triste y vacía (Fig. 37), que nos recuerda a la de 
Violeta cuando se ha presentado en el relato catatónica (Fig. 38) y delirando mientras Kira la calificaba como aún la preferida, pero tan guapa como loca.
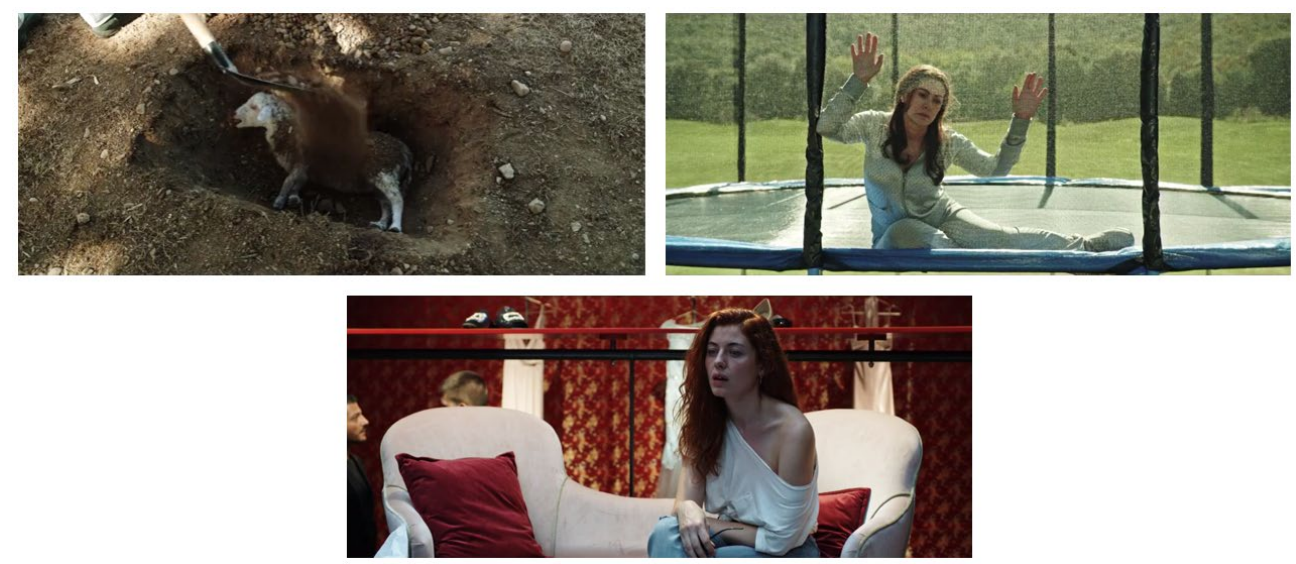

Imágenes 36 a 38: Silvio (y los otros) de Paolo Sorrentino.

\subsection{Ellas}

Silvio no descubre su rostro (Fig. 39) hasta que no está ante su mujer, Verónica (Fig. 40). Y aun así, es un rostro caracterizado, maquillado, pura caricatura. Esto cobrará sentido hacia el final del relato cuando Veronica le reproche: "No te revelas nunca, ni siquiera a mí". Retomando la alusión al pasaje del velo de Verónica, aunque a diferencia del personaje Dios, e incluso del Papa Pío XIII en The Young Pope, Silvio sí se muestre e incluso gestione con cuidado su imagen pública, su rostro no permite contactar, se resiste a ofrecer un gesto de verdad incluso a la mujer amada.
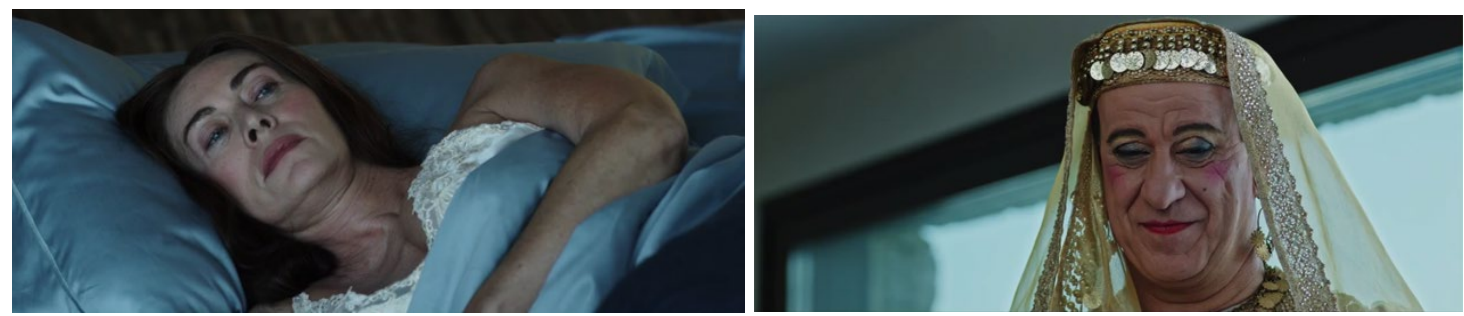

Imágenes 39 y 40: Silvio (y los otros) de Paolo Sorrentino.

Sorrentino construye el personaje de Silvio como un césar felliniano rodeado de mujeres, al servicio de una puesta en escena de la potencia de la que siempre ha alardeado. En septiembre de 2009 el abogado de Berlusconi dijo que su cliente estaba dispuesto a acudir a los tribunales para explicar que no es un gran libidinoso, pero tampoco un impotente. Como comenta Žižek, "con el despliegue público de su potencia, Berlusconi está movilizando el antiguo mito pagano del vínculo con la potencia del rey y la riqueza y prosperidad de su país: la virilidad del rey es la clave para la prosperidad de su nación" (2012: 333). El vídeo de campaña de Berlusconi muestra esta fantasía sin disimulo: unas chicas en un gimnasio bailan ofreciendo su cuerpo cantando al unísono "hay un gran 
sueño que vive en nosotros [...] ¡Menos mal que está Silvio! ¡Viva Italia! ¡La Italia que ha creído en este sueño!”. La puesta en escena fálica y obvia, con coreografías horteras y un atrezo redundante denuncian desde lo hiperbólico cómo las mujeres en serie son aspirantes al primer plano pero quedan condenadas al plano general, al plano detalle que las fragmenta o, como mucho, al busto televisivo.
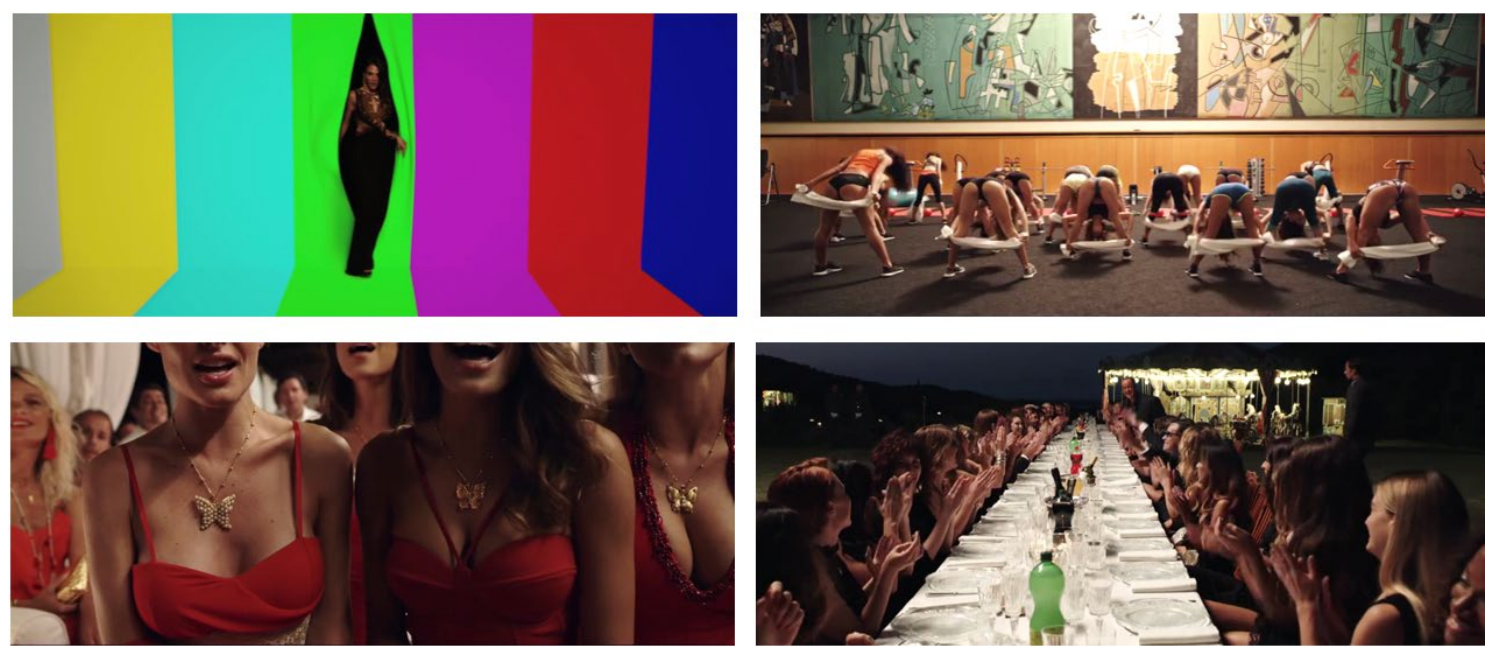

Imágenes 41 a 44: Silvio (y los otros) de Paolo Sorrentino.

Pero, como avanzábamos, Silvio trasciende la sátira y se adentra en el retrato distanciándose del amarillismo para crear, al fin y al cabo, un personaje sorrentiniano complejo, corrupto por el goce, pero vitalista y nostálgico. A Sorrentino no le interesa únicamente el escándalo, lo denunciado en los tribunales y en los periódicos, lo que ha trascendido en la esfera pública. Si en la primera parte muestra el deterioro moral de todos aquellos que fantasean con acceder a su trono, la segunda resultará mucho más íntima, centrada en el territorio de los deseos y los miedos. Lo señala como un viejo de mal aliento, como un cuerpo que necesita un salvavidas bajo la lluvia. A ella le confiesa la vacuidad que reside en sus anhelos: "la monstruosa sospecha de ser superfluo es un pensamiento que me mata". Verónica es el rostro sobre el que se escribe el paso del tiempo que a Berlusconi tanto el perturba. Al contrario que el velo sagrado que marca su nombre, Verónica no detiene el tiempo sobre el rostro y nos lega la faz con la que habría de cumplirse el sentido de la Historia. Para su ella, Berlusconi es un inventario de pérdidas: "Vendiste la cultura, la esperanza de la gente, la dignidad de las mujeres y me has vendido a mí". Ella es la mujer que le hace las preguntas que a muchos italianos les gustaría preguntar, es la única que logra ofenderlo - Silvio alardea de no ofenderse nunca por nada-. Y aunque Berlusconi también le confiesa que para él tenerlo todo no es suficiente - marcando lo ilimitado de su goce- el relato sitúa en Verónica lo que Berlusconi no puede (re)tener.

Arte y mujer, cultura y feminidad están de alguna manera hilvanadas entre las grandes carencias — paradójicamente excesivas - de Berlusconi. La enunciación se interroga sobre qué dicen de él sus objetos artísticos. Refiriéndose a las dos réplicas del cuadro de 
Courbet Mujer desnuda con perro la masajista pregunta a Verónica: "Señora, ¿por qué siempre el mismo cuadro?". "Cuando a mi marido le gusta una cosa quiere varias idénticas. Con las mujeres también es así”, responde con amargura.
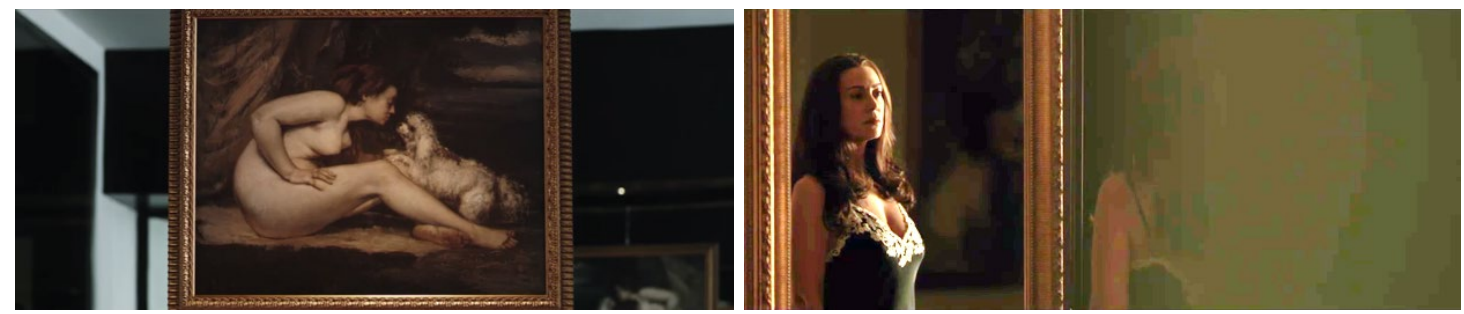

Imágenes 45 y 46: Silvio (y los otros) de Paolo Sorrentino.

Berlusconi arrebata su aura de la obra de arte, su carácter único, tratando de reproducirla y multiplicarla, porque no puede entender algo del enigma femenino. Esa búsqueda de lo idéntico a través de la acumulación de mujeres en serie parece esconder una huida de lo heterogéneo y enigmático del goce femenino (que implica el orden del ser) y escapa al goce fálico (que juega en el orden del tener). Otra escena nos confirma que también para Verónica el goce femenino se presenta como algo oscuro y fuera de toda imagen, como muestra un plano que aparece desde negro, en el que se mira al espejo y su figura se resiste a la representación (Fig. 46). Como apunta Lacan, "la mujer es Otra para el hombre como lo es para sí misma. Otra para el hombre, Otra para la mujer. Es una alteridad a la segunda potencia" (cit. en Bassols, 2017: 88). Su figura está representada de un modo radicalmente opuesto a la obviedad con la que se presentan las velinas: una luz en clave baja la dibuja y la encierra con un marco similar al del cuadro de Courbet. Es en el goce femenino inasible donde la enunciación sitúa un límite para el goce desaforado de Silvio, pues en ese registro de nada la sirve su potencia.

Que entre tantas mujeres de las que cree disponer es el goce femenino lo que a Berlusconi se le escapa también lo confirma el único plano que supone su único recuerdo presentado, su imagen más íntima e inalcanzable: la imagen de una joven Verónica de espaldas que se gira y le declara su amor ante la Catedral de Milán (Fig. 47). Este plano, profundamente bello, se propone como imagen del deseo (que abrocha la primera parte) que al escaparse explica en serie a las otras mujeres. Esto lo confirma un viejo amigo de Silvio que le confiesa que viendo en una publicación todas sus supuestas novias, "todas se parecen a Verónica".

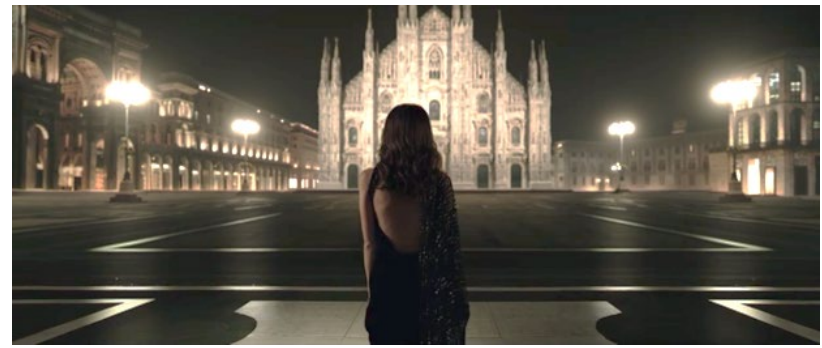

Imagen 47: Silvio (y los otros) de Paolo Sorrentino.

(C) UNED. Revista Signa 31 (2022), pp. 373-400 DOI: https://10.5944/signa.vol31.2022.29442 
Apunta Mariani (2017: 179) que en la obra de Sorrentino las mujeres van desapareciendo poco a poco a lo largo del filme para garantizar la supervivencia del personaje porque "los hombres y las mujeres tienen una relación (o correlación) mutuamente excluyente, una atracción y repulsión que persisten porque la supervivencia de uno exige la desaparición del otro". En Silvio, los cuerpos femeninos no desaparecen, sino que poco a poco conquistan todos los espacios. Sin embargo, su mujer - cuerpo central - consigue marcharse. Aunque la puesta en escena la encierre en el saltador, en la noria, en el criadero de mariposas - que aluden a los colgantes que él regala a sus amantes-, ella logra escapar de su particular jaula de cristal. Ella es la que escapa de los cuerpos en serie.

\subsection{La mierda (o el rey está desnudo)}

En el cuento El traje nuevo del emperador (Andersen, 2002) para poner a prueba a sus súbditos, éste desfila sin ropa mientras éstos aplauden y elogian su atuendo por miedo a decir la evidencia ante el poder. Sin embargo, un niño advierte sin pudor que no lleva nada puesto y el pueblo se anima a gritar sobre la desnudez del rey. Sin embargo, con más altivez aún, el monarca ordena no detener la procesión. En Silvio será el nieto —ni siquiera el espectador - el único capaz de ver esa mierda. "El abuelo no ha pisado una caca, no le ha pasado en toda su vida y nunca le pasará” — aclara Berlusconi, enseñándole el arte de la persuasión, aunque la angustia del niño se remarca con un vertigo shot que parece distanciarlo del fondo, dominado por ese falso volcán kitsch (Figs. 48 y 49)—. Que Berlusconi se haya hecho esperar tanto tiempo en el metraje y que cuando aparezca sea primero rechazado por su mujer y su nieto le vea, literalmente, la mierda bajo los pies es muy elocuente: no sólo el brillo fálico con el que le ven los otros se convierte en puro excremento para sus más allegados sino porque es el niño el que denuncia lo obvio de la escena que todos ven, pero nadie denuncia.
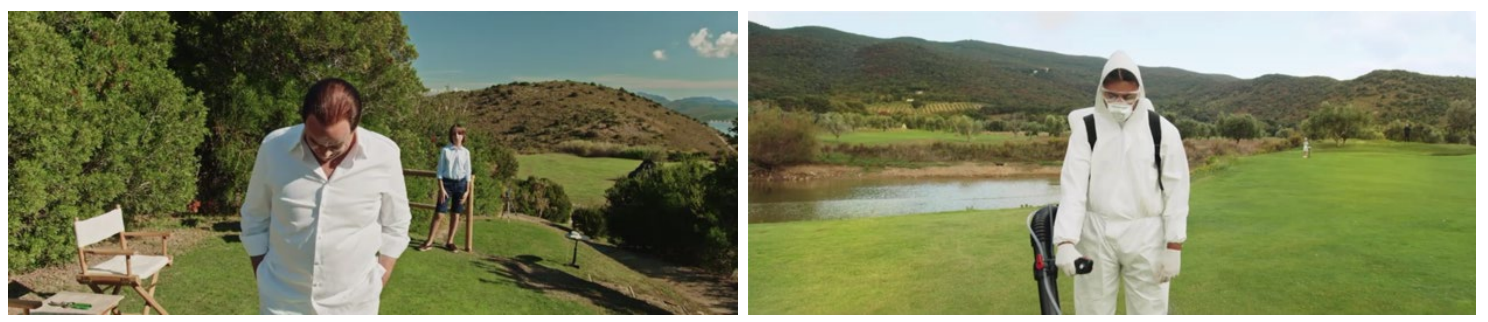

Imágenes 48 y 49: Silvio (y los otros) de Paolo Sorrentino.

La puesta en escena nos muestra que, a pesar de que los robots limpian constantemente el césped y las tierras se desinfectan, aparecen serpientes y se entierran cadáveres de animales. Aunque vista de un blanco impoluto, y aunque después de la escena de la mierda trate de gestionar su imagen en televisión seleccionando el encuadre, 
se nos muestra que hay algo que no se puede limpiar: sus negras ropas se secan al sol mientras su figura queda manchada, en sombras y cerca de la basura (Fig. 50).

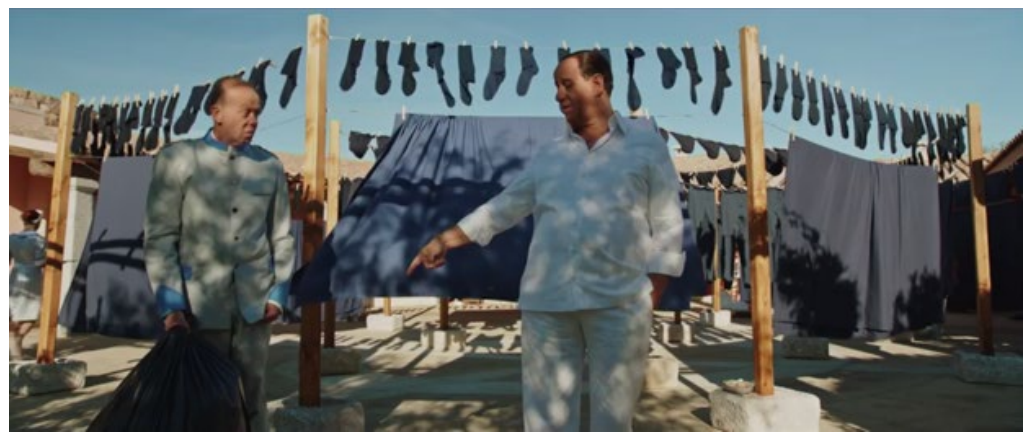

Imagen 50: Silvio (y los otros) de Paolo Sorrentino.

"El rey está desnudo" es una alegoría sobre "la espiral del silencio" (Noelle-Neumann, 2010), esto es, sobre el control social que emerge desde el concepto de opinión pública, sobre las trampas del clima del consenso. Pero también, sobre cómo una lógica subjetiva de la creencia en el Otro sostiene las mayores perversiones políticas, algo que explicaría el ascenso al poder de figuras políticas obscenas como Donald Trump y el triunfo de la posverdad.

El Otro para el que se monta el espectáculo no se encuentra más que entre quienes lo llevan a cabo. El espectáculo se dirige al deseo del Otro en el sentido de que cada individuo toma como su propio deseo el deseo nombrado por el Otro; en realidad, por él mismo, pues se engaña a sí mismo con que hay otro. Se engaña a sí mismo porque se ha acostumbrado a ese deseo. Porque es conveniente y seguro (Huson, 2010: 103).

¿No es esto lo que precisamente muestra Sergio Morra e incluso todas las mujeres que dicen desear a Berlusconi? Plegados al espectáculo ellos también son los que construyen el personaje de Berlusconi, los que lo legitiman, lo alzan y aun sabiendo de su mierda - pues les ha estallado ante sus ojos ante el mismísimo Coliseo- se acercan a él. Saben, sin duda, que serán su desecho, un juguete más al final de cada espectáculo.

\subsection{Los otros: espectadores, ciudadanos}

\subsubsection{Vender casas a los espectadores}

Decíamos que el hombre de la banca, Ennio Doris era el destinador del relato. Al confirmarle como un vendedor - $\mathrm{y}$ no como un político-, da paso a una escena fundamental que estudia las raíces de la globalización capitalista desde la intimidad de una mujer en la soledad de su hogar. A altas horas de la madrugada, Berlusconi toma al azar un nombre del listín telefónico y trata de venderle un apartamento a una señora que no lo necesita. Ella le dice que "es tarde para los sueños" y que va a colgar porque está viendo la telenovela Los días del mañana en el canal 5 -no olvidemos, propiedad del 
protagonista - Haciéndose pasar por el mejor vendedor de Italia, le adelanta el final del culebrón y añade: "Señora, ¿acaso no le gustaría que su vida se pareciese a la estupenda ficción que está viendo? Yo puedo hacerlo". Pero Berlusconi no solo parece conocer - porque es el dueño del canal 5- el desenlace de esa fícción, sino que dice conocer "el guion de la vida" — mientras se acerca a cámara (y a los espectadores) - . Finalmente, logra venderle el apartamento.

A lo largo de la secuencia, de casi siete minutos, la señora permanece sentada sola en una pequeña y oscura cocina ante el televisor, poco iluminada (Fig. 51)

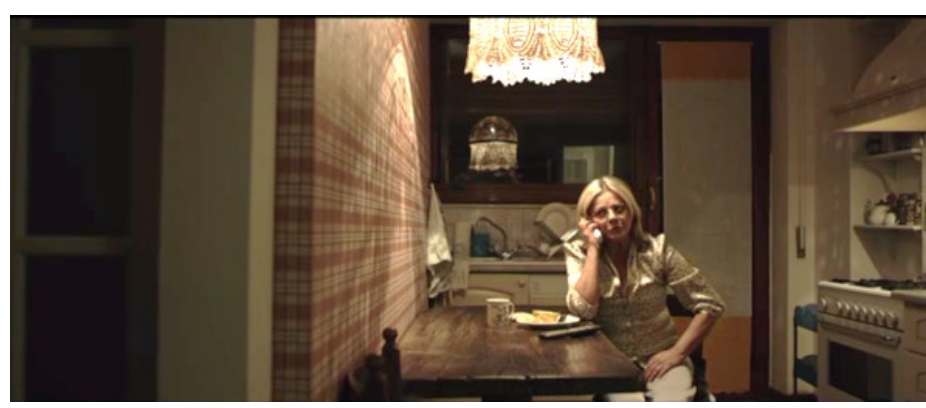

Imagen 51: Silvio (y los otros) de Paolo Sorrentino.

Berlusconi, se sienta y pasea entre sus trofeos, dejando mostrar las amplias arquitecturas y ornamentos de los espacios, siempre iluminados. El trabajo de cámara retomará el arabesco, la figura circular, el plano giratorio compuesto en torno al hombre. En el contraste de esta puesta en escena se denuncia la mentira que vende Berlusconi, urdida con un falso saber sobre los deseos y los sufrimientos de los ciudadanos.

La escena tiene tres funciones narrativas: dejar claro que Silvio nunca se ofende - algo que explica el descaro que habilita el goce - , confirmar que la oferta — no la necesidad - es la que genera la demanda y, por último, subrayar que en tiempos de posverdad en los que los ciudadanos no creen en las palabras que emanan del poder, pueden dejarse caer cómodamente en las melifluas promesas ficcionales de aquellos que se nutren de las dudas propias de la angustia y la soledad.

$\mathrm{Si}$ “el sueño berlusconiano consiste en que la voluntad general deje de ser el resultado de la competición deliberativa entre los partidos políticos y pase a ser asunto del poder mediático, que él controla casi por completo" (Naïr, 2009) es importante señalar que éste arranca en el interior de los lindes domésticos, en la extraña intimidad del hogar donde los medios ocupan un enclave central.

Esta mujer deja de estar alienada en la novela para estarlo en ese sueño sobre una casa a la que no le falta de nada, que probablemente no le permitirá dormir esta noche, pero se esfumará al despertar. Esta escena se entiende mejor si la relacionamos con un pasaje paródico de la serie, pero eliminado en el filme: cuando Berlusconi negociaba con la televisión advertimos la producción de vikingos y biopics mostrando cómo el poder controlaba las estrategias narrativas de los discursos audiovisuales. 
Si el poder se adueña "del guion de la vida" — esto es el sueño de todo totalitarismono hay lugar para la narrativa del deseo ni para el Acontecimiento. Y es que, como apunta Žižek, "la doctrina fundamental de la política posmoderna es que no hay ningún acontecimiento, que nada ocurre realmente, que el acontecimiento-verdad es un cortocircuito pasajero, ilusorio, una identidad falsa" (2007: 145). En la última parte del filme, precipitada por el terremoto en L'Aquila que se produce en el preciso momento en el que Berlusconi jura su cargo de presidente de la república, por "el interés exclusivo de la nación", Sorrentino trata de pensar esta idea. Convoca el temblor de lo imprevisto, la catástrofe, pone a prueba esa caridad que el biopic de Lady Di desvirtúa hasta el ridículo. Si hasta el terremoto el filme exhibe las perversiones de la clase de la dolce vita, del dolce far niente, la última parte del metraje exige que el concepto social, de origen romano, recupere su significado general de condición humana fundamental. Dicho de otro modo, el desenlace de Silvio (y los otros) se dedica a los otros, ya no los que mandan, sino los que actúan, los que testifican ante la pobreza del damnificado, ante el sufrimiento del ciudadano que sí necesita una casa, que requiere el cuidado y un trato ético, una consideración del habitar.

\subsubsection{Mirar al cielo a la espera del misterio. Mirar al otro a la espera de alguna verdad}

Indica Badiou:

El mundo contemporáneo es doblemente hostil a los procesos de verdad. El síntoma de esta hostilidad se hace por recubrimientos nominales: allí donde debería estar el nombre de un procedimiento de verdad, viene otro nombre que lo desplaza. El nombre cultura obstruye al de arte. La palabra técnica obstruye la palabra ciencia. La palabra gestión obstruye la palabra política. La palabra sexualidad obstruye el amor (1999: 12-13).

En Silvio (y los otros) sobornar es convencer, vender es engañar, comprar es seducir, el altruismo es la mejor manera de ser egoísta. Precisamente porque todo resuena a una mentira compartida, porque nadie denuncia que el rey está desnudo, porque la política posmoderna está recorrida por el escepticismo y la posverdad, Badiou insista en que "los "milagros ocurren... (empleando el término 'milagros' con todo su peso teológico)" (Žižek, 2007: 145). Sorrentino, como veremos, abre un espacio para la ética y para la verdad, por eso termina con personajes mirando al cielo — otro de sus rasgos autorales-, rescatando la estatua de Cristo de los escombros del terremoto.

Cuando Berlusconi promete ante los damnificados construir una "new town" desde fuera de campo una señora grito: "Jesucristo, que nos devuelvan a Jesucristo". El final de Silvio está inevitablemente hilvanado con esa experiencia de vacío teológico, esa ambigüedad de la creencia que nos sacude en presencia de los restos (artísticos) que todavía flotan en las constelaciones de los grandes relatos. Sería demasiado arriesgado — e ingenuo - leer la ascensión de Cristo entre los obreros como una suerte de anhelo de 
retorno de divinidad más o menos normativa que taponara el tan cacareado relativismo y que arrastrara, a su paso, un sistema ético objetivo, verificable y exento de fallas. Delirio histórico que Sorrentino no repite - no lo hará tampoco en sus reflexiones sobre la Iglesia o sobre la naturaleza misma de la belleza - , sino que más bien parece apuntar a un anhelo directo de, como decíamos al principio, una fundamentación concreta sobre la que pensar el acto ético.

En efecto, si miramos las imágenes vemos que son dos los operadores textuales: una muchedumbre que come, derrotada, en el lugar de la tragedia (Fig. 52) y un único cadáver "sublimado" que, en lugar de los cuerpos despedazados, puede pasearse por el cielo (Fig. 53). Esta escena final, precisamente retoma y espeja la escena inicial de La dolce vita (1960) de Federico Fellini, en quien Sorrentino no deja de mirarse continuando su legado: allí también un Cristo en helicóptero sobrevuela las obras que reconstruyen la Roma arrasada por la guerra ante la mirada de los obreros y los cuerpos ociosos (Fig.54 y 55).
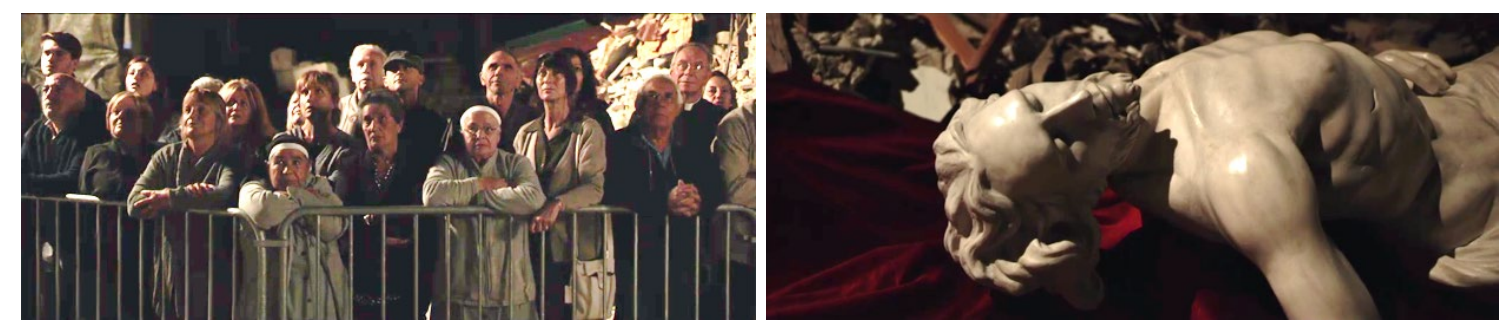

Imágenes 52 y 53: Silvio (y los otros) de Paolo Sorrentino.
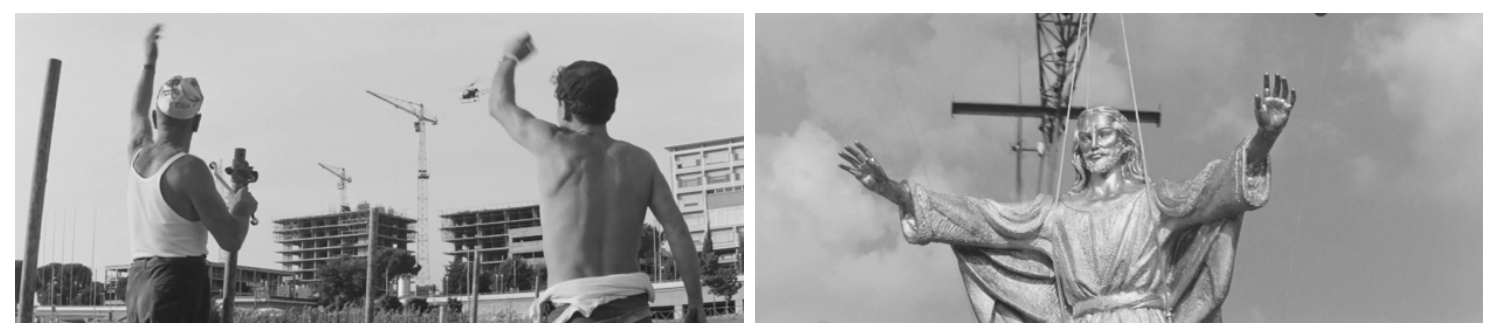

Imágenes 54 y 55: La dolce Vita de Federico Fellini.

El lugar del cadáver de un dios es, como bien señala Nietsche - especialmente en su aproximación de La gaya ciencia (2011) — el lugar en el que la ausencia de una verdad objetiva nos atraviesa y nos llena de pánico. Al contrario que en el cine religioso, aquí Cristo no emerge del sepulcro ni asciende gloriosamente al tercer día, sino que se ofrece, mutilado e incompleto, al silencio de esos otros que quedaban encerrados en el paréntesis que marcaba el título de la película. Un casi-silencio, el ruido de las olas que invade la banda sonora y que resulta extrañamente opresivo y definitivo en un metraje que ha incorporado a lo largo de todo su recorrido un diseño sonoro lleno de música, gritos, ruidos y declaraciones hasta rozar lo insoportable.

El hecho de que haya algo que no se pueda decir, de que algo no se pueda concretar en su sentido último, es - como ocurría en el filme de Moretti- el bofetón definitivo contra el estatuto transparente e idiota de las imágenes que los canales de Berlusconi 
ponen en circulación, día tras día. El misterio al que hacíamos referencia desde el principio del texto queda ahora cifrado en esa hermosa dicotomía entre símbolo y signo religioso que Joseph Campbell (2019) trabajó afanosamente en los márgenes de Jung, y que aquí nos golpea con toda su fuerza: estamos frente a la imposibilidad de clausurar la creencia o el gesto ritual en una verdad histórica definitiva y redentora. Nos encontramos, más bien, ante la reivindicación de una ambigüedad total en lo que al pensamiento trascendental se refiere como condición previa y necesaria para el encuentro con las preguntas fundamentales que rodean nuestra existencia.

Anotaba Hannah Arendt que "ninguna clase de vida humana, ni siquiera la del ermitaño en la agreste naturaleza, resulta posible sin un mundo que directa $o$ indirectamente testifica de la presencia de los otros seres humanos" (2005: 37). Si como hemos analizado, Berlusconi decía que "lo social solo puede ser gestionado por un asocial", y exigía que los rostros no se crucen, Sorrentino reserva la poética de su característico "travelling paseante" (Bort y Sorolla: 2018) para el último plano. Mientras nos mece el sonido del mar, rescata los rostros de la oscuridad con un travelling circular que abraza a los "ellos" (LORO), los que (re)construyen y sostienen al otro (que no es invisible pero sí queda fuera de campo en la política neoliberalista). Silvio (y los otros) es una sátira sobre el goce contemporáneo, pero también una poética lección de alteridad.

\section{CONCLUSIONES}

Tras el análisis textual consideramos que podemos articular las siguientes conclusiones:

1. Mientras que la posverdad nombra el declive de la palabra y la responsabilidad que ésta implica, el estilo visual de Sorrentino reivindica un cine contra la transparencia en el que subraya la enunciación, que no es otra cosa que el compromiso ético que un sujeto toma con el discurso. Y, a diferencia de las sátiras audiovisuales que denuncian, piensan y reconstruyen la crisis política y económica de 2008 — véanse, por ejemplo, la ya citada El lobo de Wall Street, La Gran Apuesta (The Big Short, Adam McKay, 2016) o en una esfera europea El capital (Le Capital, Costa-Gavras, 2012) - Silvio (y los otros) propone la recuperación y la reconstrucción de cierta mirada hacia lo sagrado como enigma ante el significante o el misterio de la palabra.

2. Silvio (y los otros) se propone como una sátira del cinismo del poder contemporáneo y sobre la obscenidad política pero irradia la crítica al localizar aquellas fantasías que sostiene la opinión pública: el rey está desnudo o la espiral del silencio en los mass media, el mito del rey potente y la fantasía del amo invisible en la teoría de la conspiración.

3. La puesta en imágenes de Silvio (y los otros) trasciende la sátira para estudiar a Berlusconi como personaje complejo. Aunque en la ficción su mujer dice que él 
es "una larguísima e ininterrumpida puesta en escena, Silvio" y que nunca se revela, la enunciación lo invita a ello al construirlo como un personaje sorrentiniano que goza y desea en un mundo en el que colisiona lo viejo y lo nuevo, la senectud y la juventud, la decadencia y el vitalismo, el jolgorio y la soledad, lo masculino y lo femenino, los santos y las prostitutas, la magia y el soborno, la política y el pueblo, el surrealismo y el realismo, la inspiración y el aburrimiento, lo cómico y lo trágico, lo elegante y lo vulgar, lo majestuoso y lo carnavalesco, lo obvio y lo obtuso, la cultura y el espectáculo, el vacío y el exceso, lo trascendente y lo terrenal.

4. Silvio (y los otros) traza un interesante e irónico trasvase discursivo desde un Silvio anónimo que vende apartamentos a una espectadora televisiva hasta un Berlusconi que promete casas a los que sufren. También, la narrativa evoluciona y se transforma desde una puesta en imágenes, obvia y obscena, que retrata a Silvio como un Otro rodeado de otros invisibles, a una puesta en imágenes oscura que se pregunta por el horror, por la creencia en un Otro simbólico y por la ética del otro). De este modo, la sátira política deviene un poema sobre la alteridad.

Con todo, ya podemos recordar y comprobar nuestra hipótesis: Silvio (y los otros) no cae en la obscenidad y el exceso de lo que representa porque no se adscribe a la tradición naturalista a favor de un cine transparente, sino que reivindica un cine de la expresión. Precisamente su posición ética emerge de las decisiones enunciativas - especialmente sobre la puesta en escena- que le permiten trascender la sátira para construir un retrato del Berlusconi y hacer una propuesta ética: en tiempos de la posverdad, recuperemos el misterio.

En definitiva, la escritura autoral Sorrentino trata de rescatar al sujeto del escepticismo, individualismo y el desencanto político e informativo. En tiempos de posverdad, Sorrentino reivindica una verdad que, como decía Lacan (2005: 254), tenga estructura de ficción.

\section{REFERENCIAS BIBLIOGRÁFICAS}

ANDERSEN, H. C. (2002). El traje nuevo del emperador. Bogotá: Norma.

ARENDT, H. (2005). La condición humana. Barcelona: Paidós.

Aumont, J. y MARIE, M. (1990). El análisis del film. Barcelona: Paidós.

AZARA, P. (2002). El ojo y la sombra. Una mirada al retrato en Occidente. Barcelona: Gustavo Gili.

BAdiou, A. (1999). San Pablo: la fundación del universalismo. Rubí: Anthropos.

BASsols, M. (2017). Lo femenino, entre centro y ausencia. Buenos Aires: Grama Ediciones. 
BAZIN, A. (2004). ¿Qué es el cine? Madrid: Rialp.

BorT, I. Y SOROLlA, T. (2018). "A lo largo de la atalaya: el travelling descreído del opening de The Young Pope". Millars. Arte Especular. Nudos entre pintura y cine XLV, 149-174.

CAMPBELl, J. (2019). El vuelo del ganso salvaje: Exploraciones en la dimensión mitológica. Barcelona: Kairós.

CARmona, R. (2006). Cómo se comenta un texto filmico. Madrid: Cátedra.

Castro de Paz, J. L. y Cerdán, J. (2011). Del Sainete al Esperpento: Relecturas del cine español de los años 50. Madrid: Cátedra.

CAtalà, J. M. (2001). La puesta en imágenes. Conceptos de dirección cinematográfica. Barcelona: Paidós.

(2012). El murmullo de las imágenes. Imaginación, documental y silencio. Santander: Shangrila.

Costa, J. (2019). "La seducción de la "videocracia"”. El País, 4 de enero. Disponible en línea:https://elpais.com/cultura/2019/01/02/actualidad/1546454815_544059.htm $l[21 / 07 / 2021]$.

Daney, S. (2004). El cine: Arte del presente. Buenos Aires: Santiago Arcos.

EsPigAdo, M. (2017). Reír por no llorar. Identidad y sátira en el fin del milenio. Zaragoza: Prensas de la Universidad de Zaragoza.

GARCÍA-CATALÁN, S. (2018). "Los desheredados. El Otro pulverizado en nuestra cultura visual”. En Crisis de lo real. Representaciones de la crisis financiera de 2008 en el audiovisual contemporáneo, J. Marzal Felici et al. (eds.), 91-128. Valencia: Tirant.

GonzÁlez RequenA, J. (2006). Clásico, manierista, postclásico. Los modos del relato en el cine de Hollywood. Valladolid: Castilla Ediciones.

Holm, N. (2017). Humor as Politics: The Political Aesthetics of Contemporary Comedy. London: Palgrave Macmillan.

Huson, T. (2010). "Verdad y contradicción: leer a Hegel con Lacan". En Lacan: los interlocutores mudos, S. Žižek (ed.), 77-106. Madrid: Akal.

HutcheOn, L. (1994). Irony's Edge: The Theory and Politics of Irony. New York: Routledge.

LACAN, J. (2005). Seminario 4. La relación de objeto. Buenos Aires: Paidós.

LÁzARO, L. A. (1996). "La narrativa de Tom Sharpe. Entre la farsa y la sátira”. Estudios de literatura en lengua inglesa del siglo XX3, 227-234.

LÉVINAS, E. (2000). Ética e infinito. Madrid: La Balsa de la Medusa.

LóPEZ, V. (2019). "Silvio (y los otros): otra salvaje clase magistral de Paolo Sorrentino". Espinof, 4 de enero. Disponible en línea: https://www.espinof.com/criticas/silviootros-nueva-salvaje-clase-magistral-paolo-sorrentino [21/07/2021].

Magi, L. (2017). "Sorrentino retrata la vida de excesos de Berlusconi”. El País, 10 de octubre. Disponible en línea: https://elpais.com/elpais/2017/10/18/gente/ 1508344773_361450.html[21/07/2021]. 
MARIAni, A. (2017). “The Empty Space of Sorrentino's Female Characters in The Great Beauty and Consequences of Love". En Representations of Female Identity in Italy from Neoclassicism to the $21^{\text {st }}$ Century, N S. Giovanardi Byer \& F. Cecchini (eds.), 170-186. Newcastle: Cambridge Scholars Publishing.

MARZAL, J. y SOLER, M. (2018). "La crisis financiera de 2008 a través de la fotografía y el cine mainstream". En Crisis de lo real. Representaciones de la crisis financiera de 2008 en el audiovisual contemporáneo, J. Marzal Felici et al. (eds.), 129-152. Valencia: Tirant.

MARZAL, J. Y Gómez TARín, F. J., EDS. (2007). Metodologías de análisis del film. Madrid: Edipo.

Milner Davis, J. (2003). Farce. New Brunskwick: Transaction Publishers.

NAÏr, S. (2009). “¿De qué es síntoma Berlusconi?”. El País, 27 de junio. Disponible en línea: https://elpais.com/diario/2009/06/27/opinion/1246053612_850215.html [21/07/2021].

Nietzsche, F. (2011). La Gaya Ciencia. Madrid: EDAF.

Noelle-Neumann, E. (2010). La espiral del silencio. Opinión pública: nuestra piel social. Barcelona: Paidós.

Rodríguez FERRÁndiz, R. (2018). Máscaras de la mentira: el nuevo desorden de la posverdad. Valencia: Pre-textos.

Rodríguez SERrANO, A. (2017). "El hombre, el otro y Dios: reflexiones sobre la mirada y la serialidad en The Young Pope". L'Atalante: Revista de Estudios Cinematográficos 24, 85-97.

(2018). Nanni Moretti. Madrid: Cátedra.

Rodríguez Torres, F. (2018). "Silvio (y los otros). Crítica". Caimán. Cuadernos de Cine, 77.128, 62.

Rubio Alcover, A. (2012). "Sorrentino para diletantes". Quaderni del CSCI 8, 228-234.

VERDÚ, D. (2018). "Sorrentino: 'Mi película no es un ataque a Berlusconi'”. El País, 3 de mayo. Disponible en línea: https://elpais.com/cultura/2018/05/03/actualidad/ 1525336286_332854.html [21/07/2021].

Zambrano, M. (2011). Notas de un método. Madrid: Tecnos.

ZAPPITELLI, P. (2016). “Terremoto, a L'Aquila il 'miracolo' delle casette Berlusconi”. Il Tempo, 6 novembre. Disponible en línea:

https://www.iltempo.it/cronache/2016/11/05/news/terremoto-a-l-aquila-ilmiracolo-delle-case-di-silvio-berlusconi-1023255/[21/07/2021].

ŽIŽEK, S. (2007). El espinoso sujeto. El centro ausente de la ontología política. Buenos Aires: Paidós.

(2011). El acoso de las fantasías. México: Siglo Veintiuno Editores.

(2012). Viviendo en el final de los tiempos. Madrid: Akal.

ZuNZUNEGUI, S. (2005). Las cosas de la vida: lecciones de semiótica estructural. Madrid: Biblioteca Nueva. 
ZunZuneGui, S. Y ZumAlde, I. (2019). Ver para creer: avatares de la verdad cinematográfica. Madrid: Cátedra.

(c) $\$\left(\begin{array}{l}\text { This work is licensed under a Creative Commons Attribution- } \\ \text { NonCommercial-NoDerivatives } 4.0 \text { International (CC BY-NC-ND). }\end{array}\right.$

El/la firmante del artículo se responsabiliza de las licencias de las imágenes incluidas.

Fecha de recepción: 15/01/2021

Fecha de aceptación: 28/07/2021 